\title{
乳癌手術におけるブレード型マイクロ波 メスの使用経験
}

$\begin{array}{lllll}\text { 長浜 実穂, 田伏 } & \text { 克惊, 山本 誠己, 坂口 } & \text { 雅宏 } \\ \text { 下間 仲裕, 南 浩二, 有井 一雄, 岡 } \text { 正巳 }\end{array}$

Radical operation of the breast cancer using blade type microwave scalpel

Miho Nagahama, Katsuyoshi Tabuse, Seiki Yamamoto, Masahiro Sakaguchi

Nakahiro Shimotsuma, Koji Minami, Kazuo Arii and Masami Oka.

\begin{abstract}
Recently, we developed the new tool, which has a blade type scalpel at the tip of the Microtaze, and it can coagulate and cut at the same time. This improved Microtaze was used for the radical operation of the breast cancer, then comparison and examination was performed between the used group and the non-used group of the new Microtaze.

The operation was able to finish with only some ligations by using this scalpel, and almost equal between the two groups in amount of bleeding and operation time. No peculiar complications were observed in the used group.

In future, this operation will be finished with less bleeding and less operation time. The new Microtaze will be used not only breast cancer but also various operations.
\end{abstract}

国立大阪南病院 外科

Department of Surgery, Osaka-Minami National Hospital

key words: blade type microwave scalpel, breast cancer 
はじめに

癌切除術において輸血が予後に及ぼす影響 は，以前より多数報告されており ${ }^{1-6)}$ ，そのほ とんどが予後に悪影響を与えるという報告であ る。乳癌切除術に扔いても同様の報告が散見さ

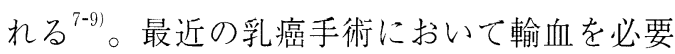
とすることはほとんどなくなったが，稀に不測 の出血をきたすことがある。最近我々は, 強力 な止血力を有するマイクロターゼの先端にブ レード型メスを装着し, 組織を凝固しながら切 開できる新しい器械を開発し ${ }^{10)}$, 種々の手術に 使用している。ここでは改良型マイクロターゼ OTー110M を使用した乳癌根治術の手術手技に ついて述べ，マイクロターゼ使用群と非使用群 との比較検討を行ったので報告する。

\section{対象と方法}

1991年2月から 8 月までの 7 カ月間に当科に てマイクロターゼを使用し, 乳癌根治術を施行 したのは定型的乳房切断術 4 例, 非定型的乳房 切断術 11 例の 15 例, 平均年齢は 51.3 歳であっ た。1990年に乳癌根治術を施行したのは18例 で，拡大乳房切断術を施行した 4 例を除くと， 定型的乳房切断術 9 例, 非定型的乳房切断術 5 例の14例で平均年齢は51.3歳であった。この両 者を対象とし, 手術時間, 出血量, ドレーン留 置期間，合併症について比較検討を行った。

\section{手術手技}

1）皮膚切開予定線に沿って円刃刀で浅い切開 を行う。この時の深さは, 創縁より皮下脂肪 が漏出しない程度とする（図１）。
2) 切開創の外縁に約 $4 \mathrm{~cm}$ 間隔に鉗子をかけ, これを上方に引かせ, 術者は左手にガーゼを 持ち, 乳腺組織を下方へ押し付けながら, こ の間の緊張した組織をマイクロ波メスを使っ て皮膚表面よりそぎ落とすように切開を進め る(図 2 )。

3 ) 出血が認められた場合は, 出血部位にメス の側面を押し当てて凝固する。結紮は必要と しない(図 3)。

4 ) 大胸筋前面の剝離は大胸筋筋膜が切除乳房 側に付着するようにし, 残存する大胸筋の前 面が筋組織の色一色になるようにする（図 4 )。

5 ）大胸筋外縁を鋭的に切離し裏側に入り, 大 小胸筋間の脂肪織及び Rotter のリンパ節を 郭清する。この際, 大胸筋外縁に入る栄養血 管と神経及び小胸筋を貫通してくる神経を損 傷しないように心がける（図５）。

6 ）外側胸動静脈より外側の腋窝領域の郭清 は，腋窩動脈に沿って内側より外側に向かっ て進める。腋窩の郭清が終了すれば乳房は en-bloc に切除される (図 6 )。

7 ) 切除終了後の術野である（図 7)。

8 ）定型的乳房切断術の場合は, 大胸筋上腕骨 付着部下縁より左手を大胸筋間溝入通し, 大 胸筋を上腕骨にできるだけ近くでマイクロ波 メスで切離する。電気メスと違い, 筋肉の攣 縮が起こらないため, 容易に操作が行え る。大胸筋を翻転すると小胸筋が現れ，同様 に切離する(図 8 )。

9 ）鎖骨下部の郭清より連続して大胸筋胸壁付 着部の切離に移る。肋間より出る内胸動静脈 の穿通枝を止血しやすくするため, 大胸筋を 


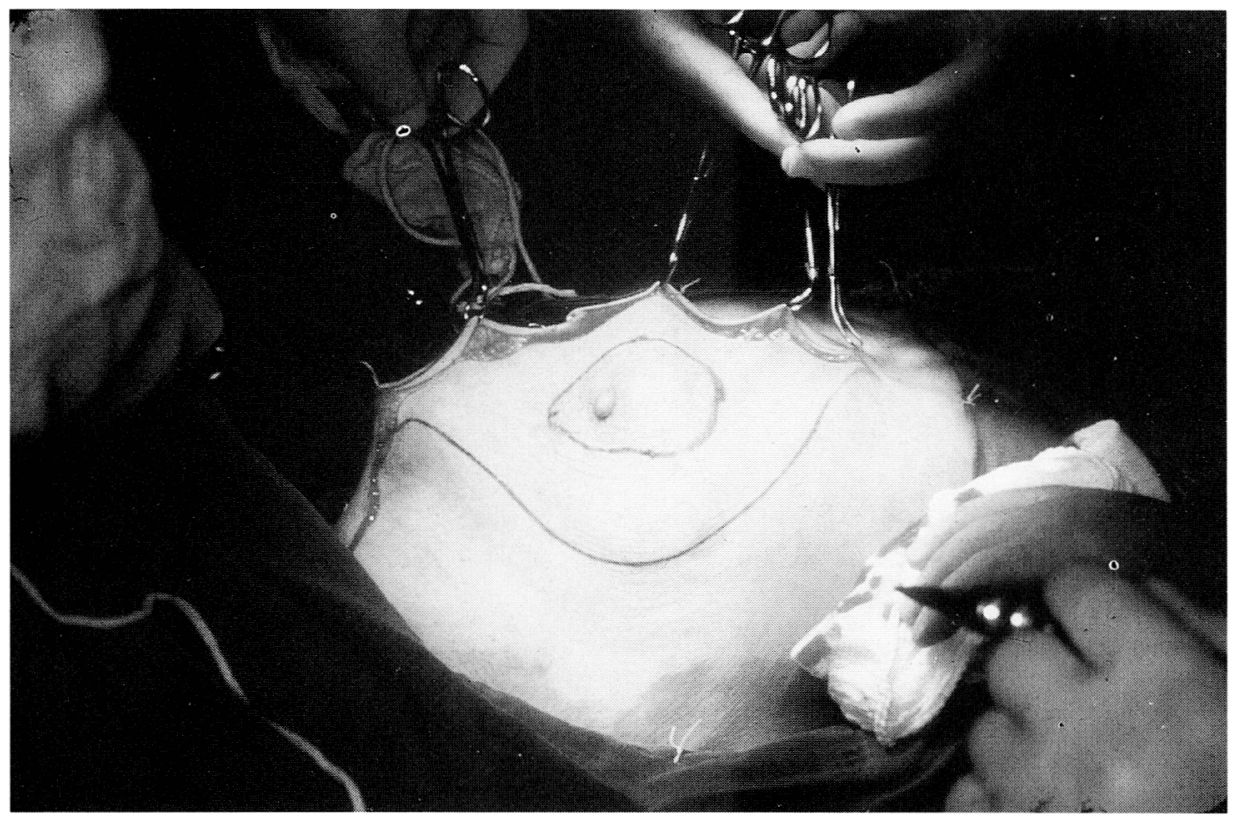

図 1

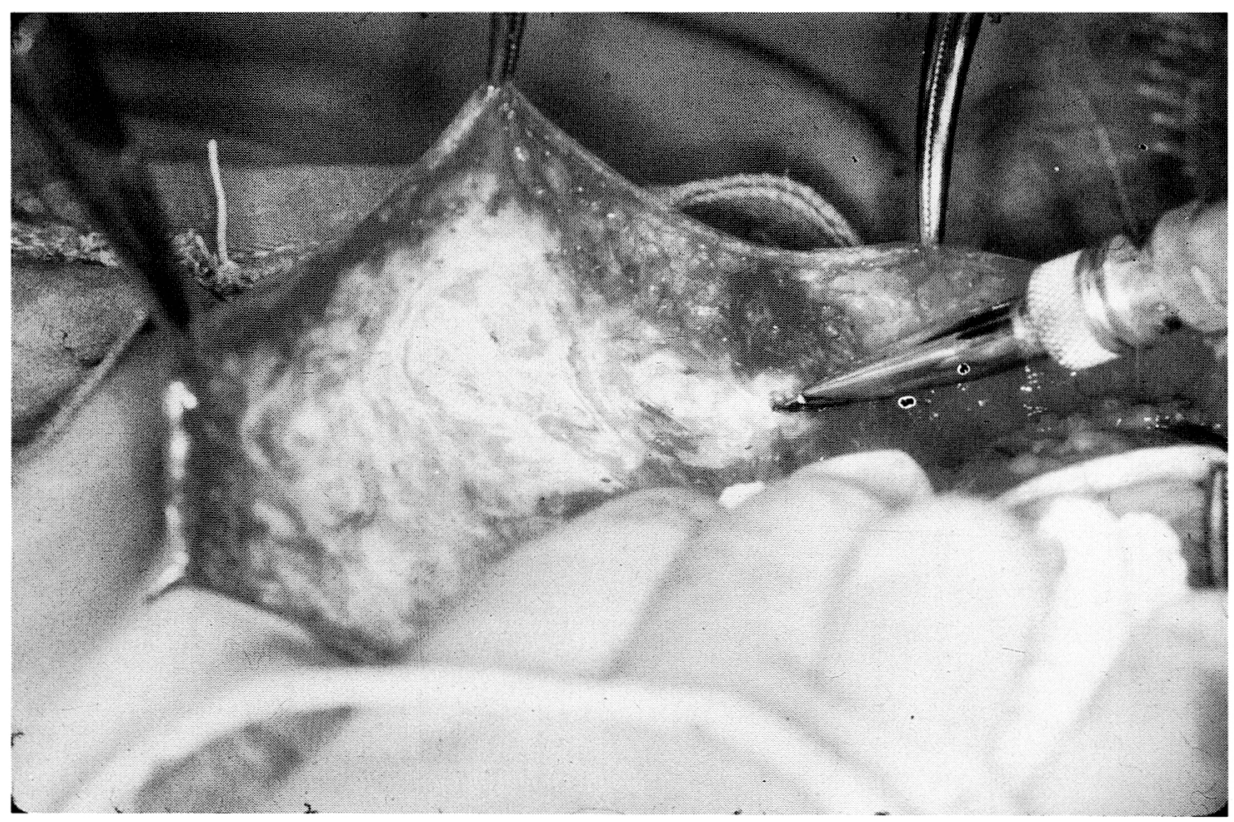

図 2 


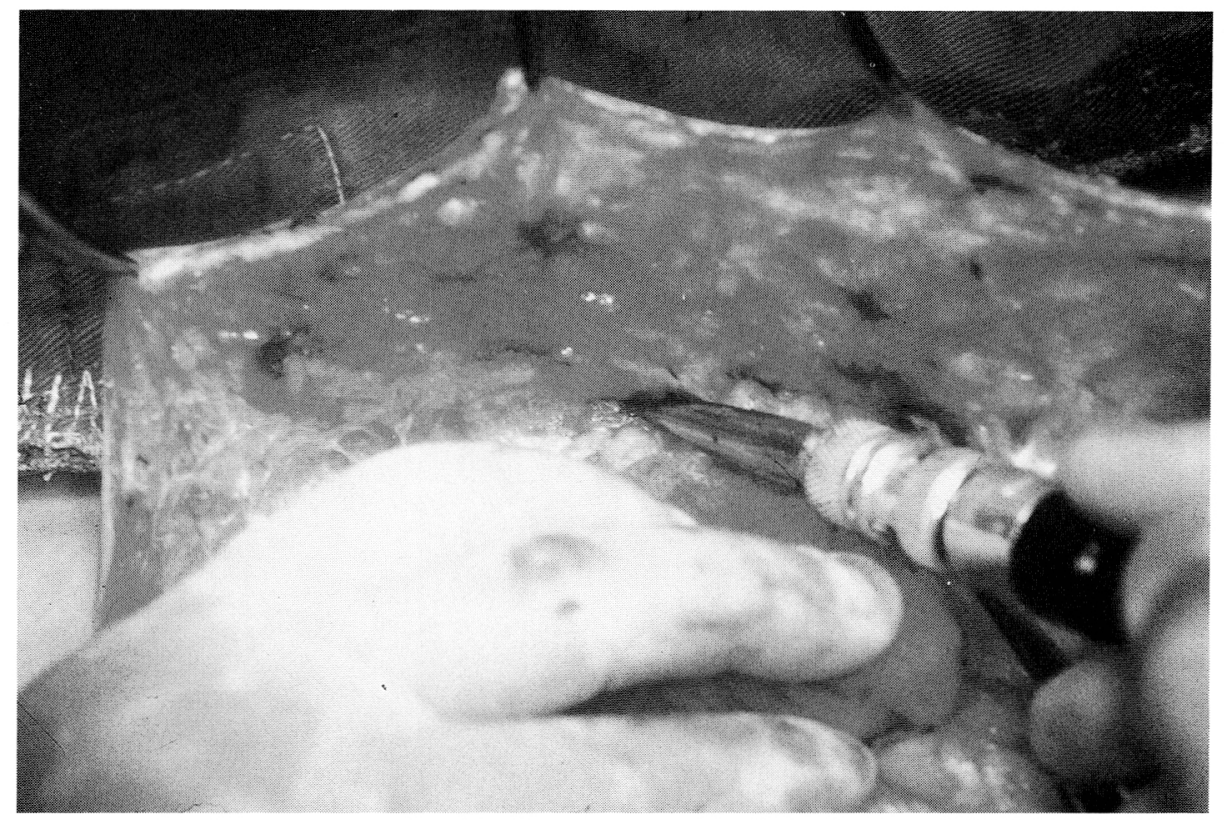

図 3

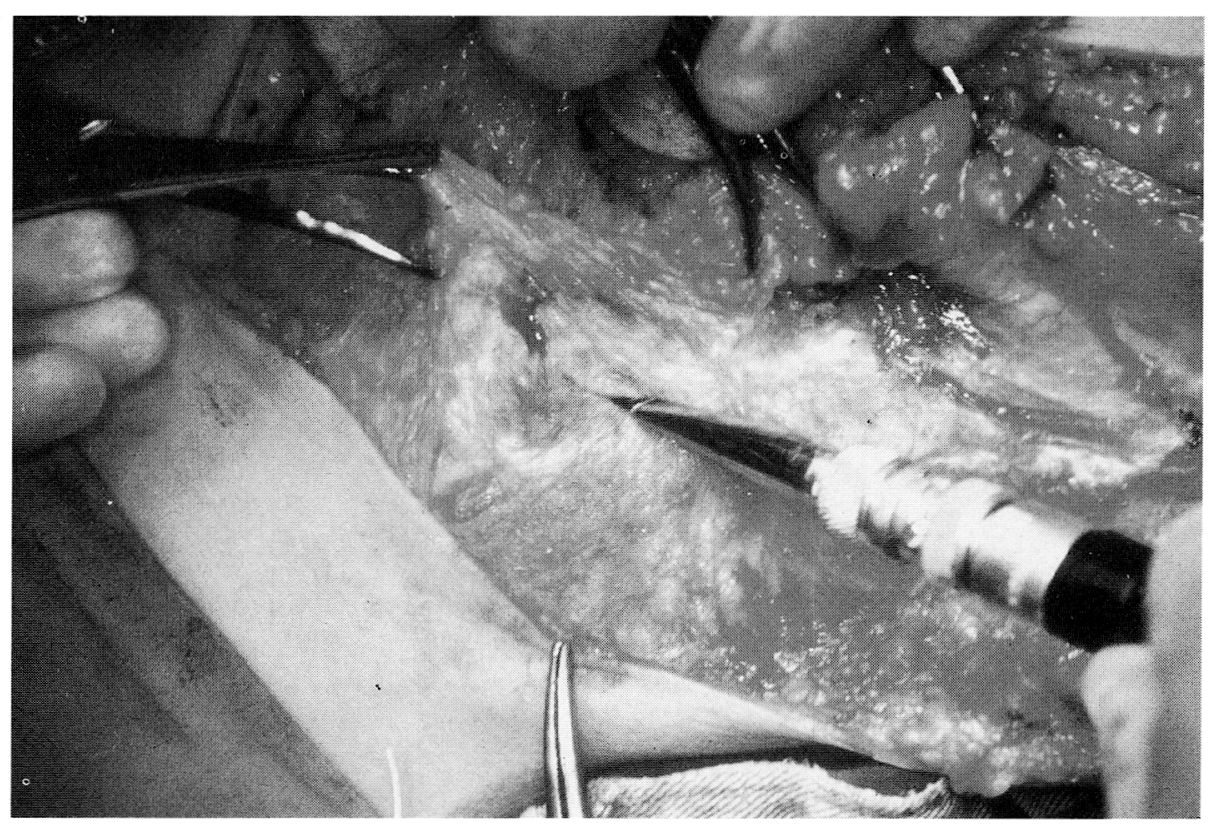

図 4 


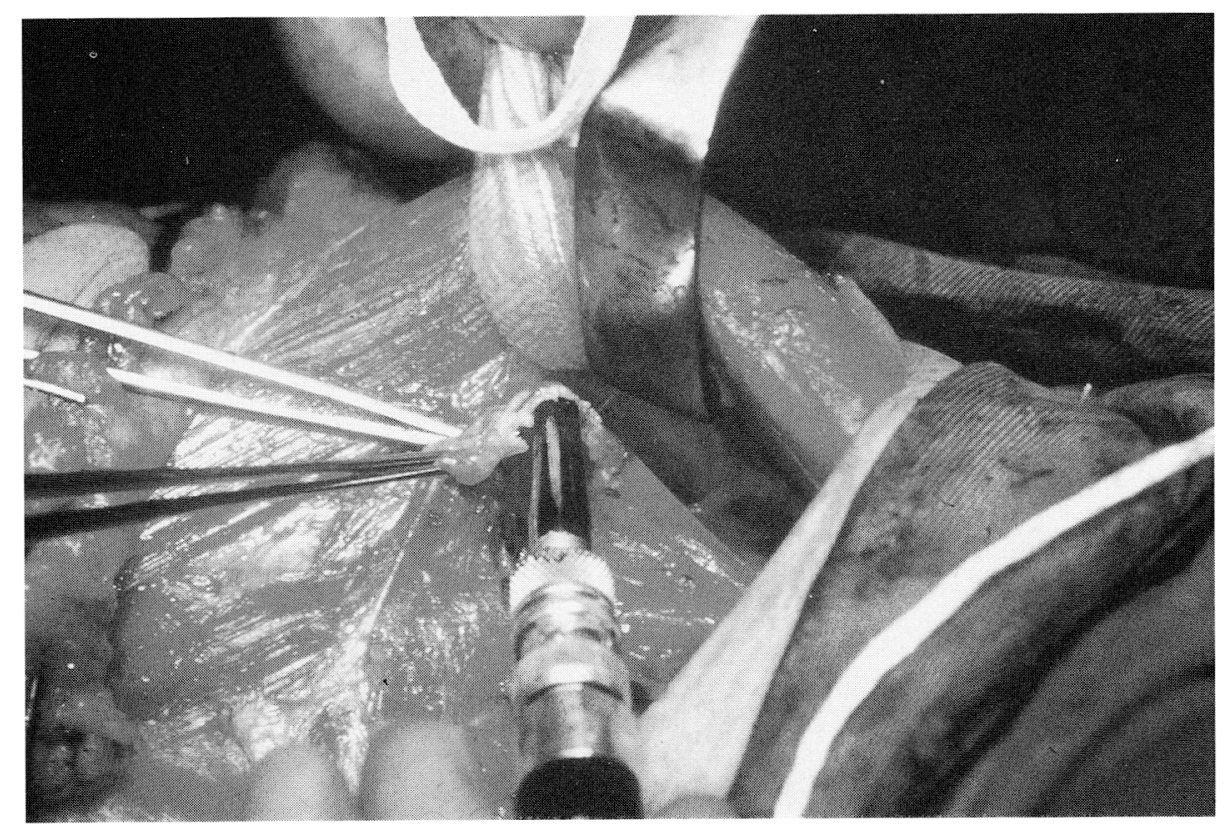

図 5

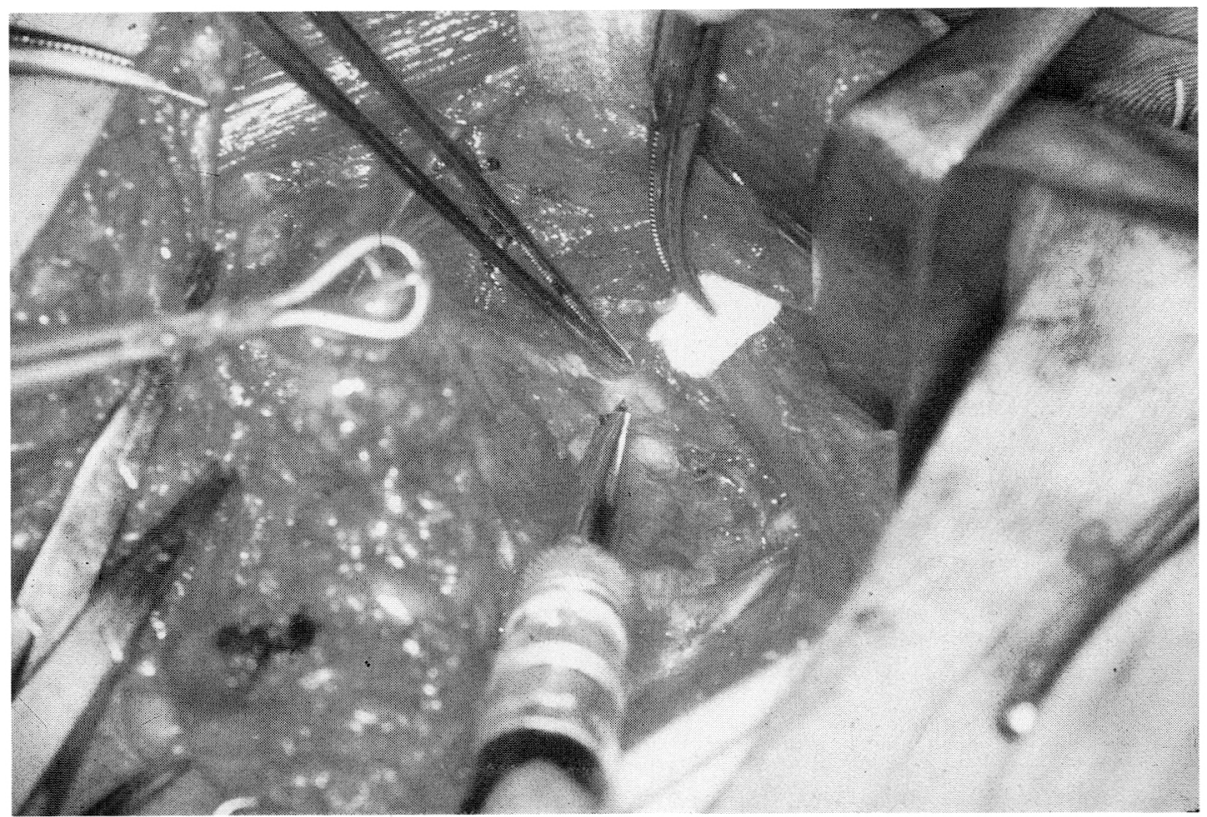

図 6 


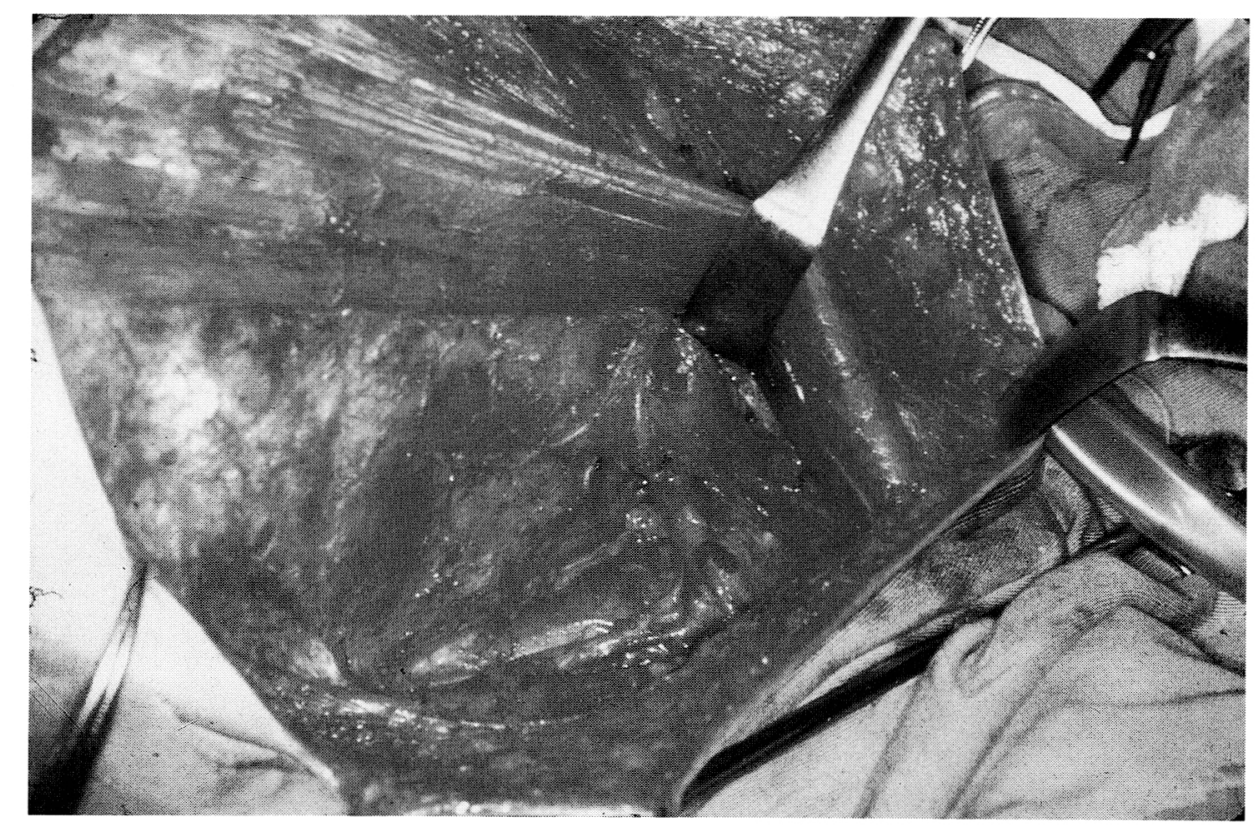

図 7

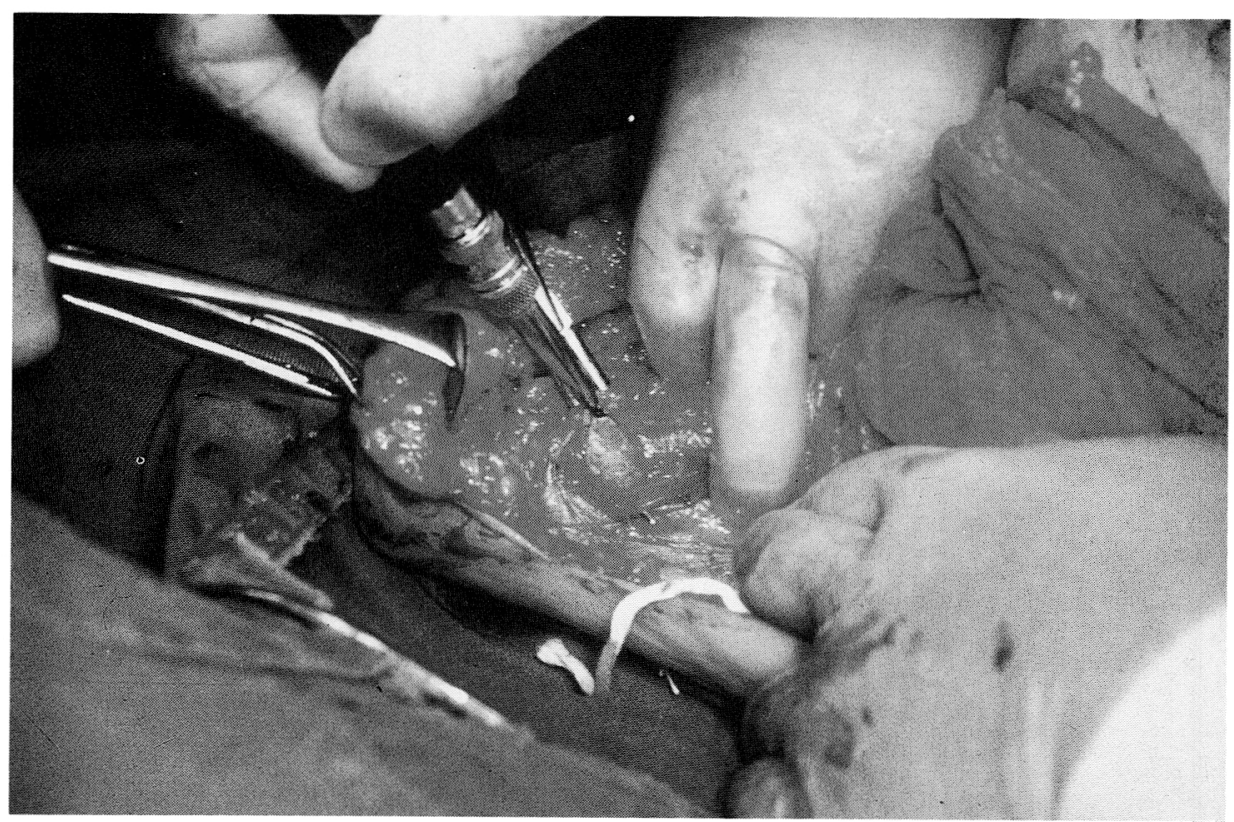

目 8 
約 $5 \mathrm{~mm}$ ほど残して切離し，穿通枝はマイクロ

波メスにて充分凝固した後切離する（図 9 )。

10）大胸筋断端より出血が認められた場合は,
マイクロ波メスの側面を穿通枝に押し当て, 充分に凝固する。結紮は全く必要としない (図10)。

11）切除終了後の術野である（図11）。

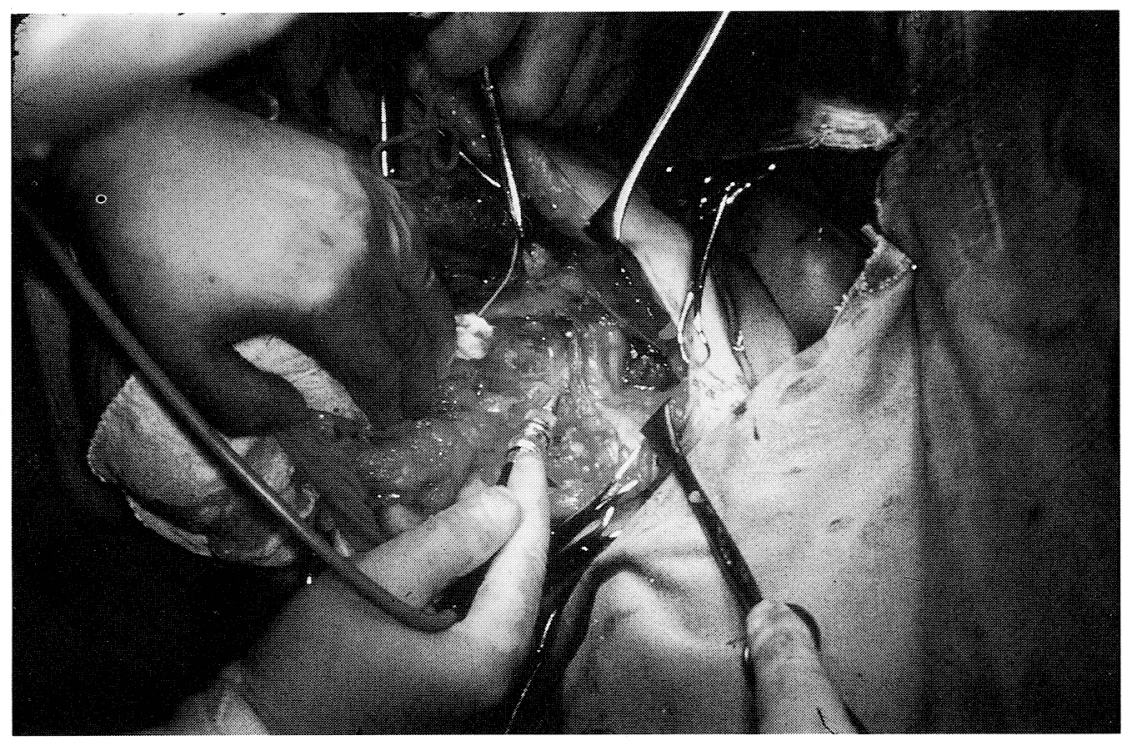

図 9

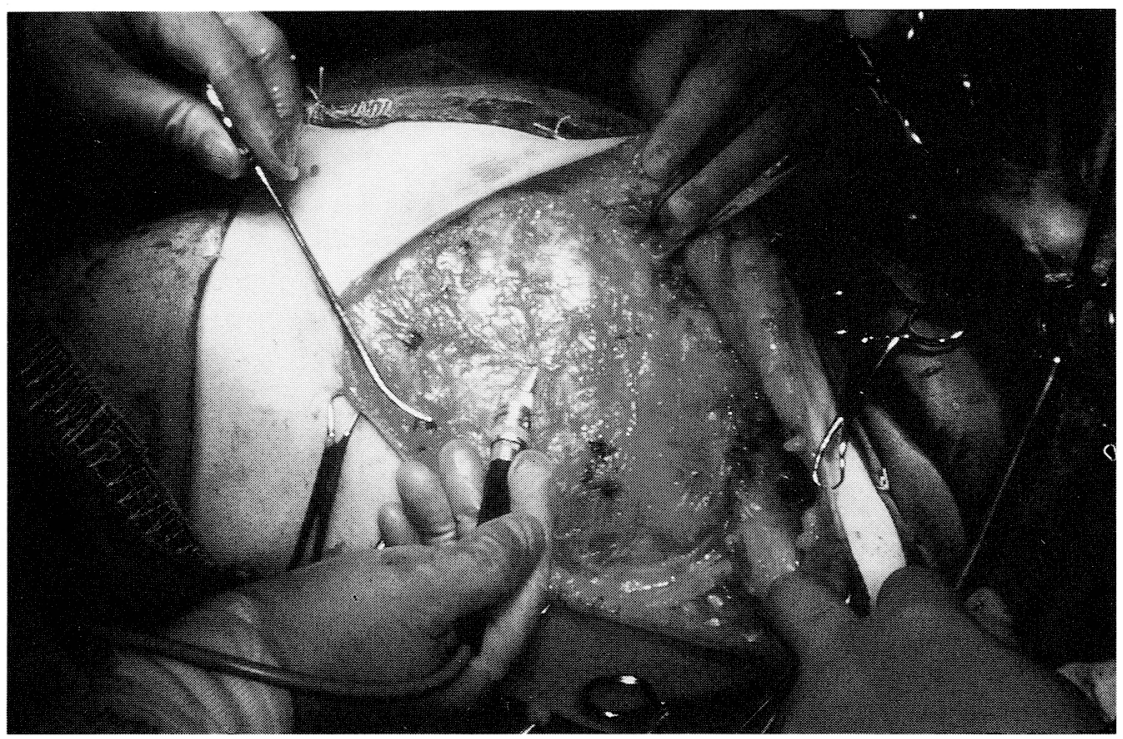

図10 


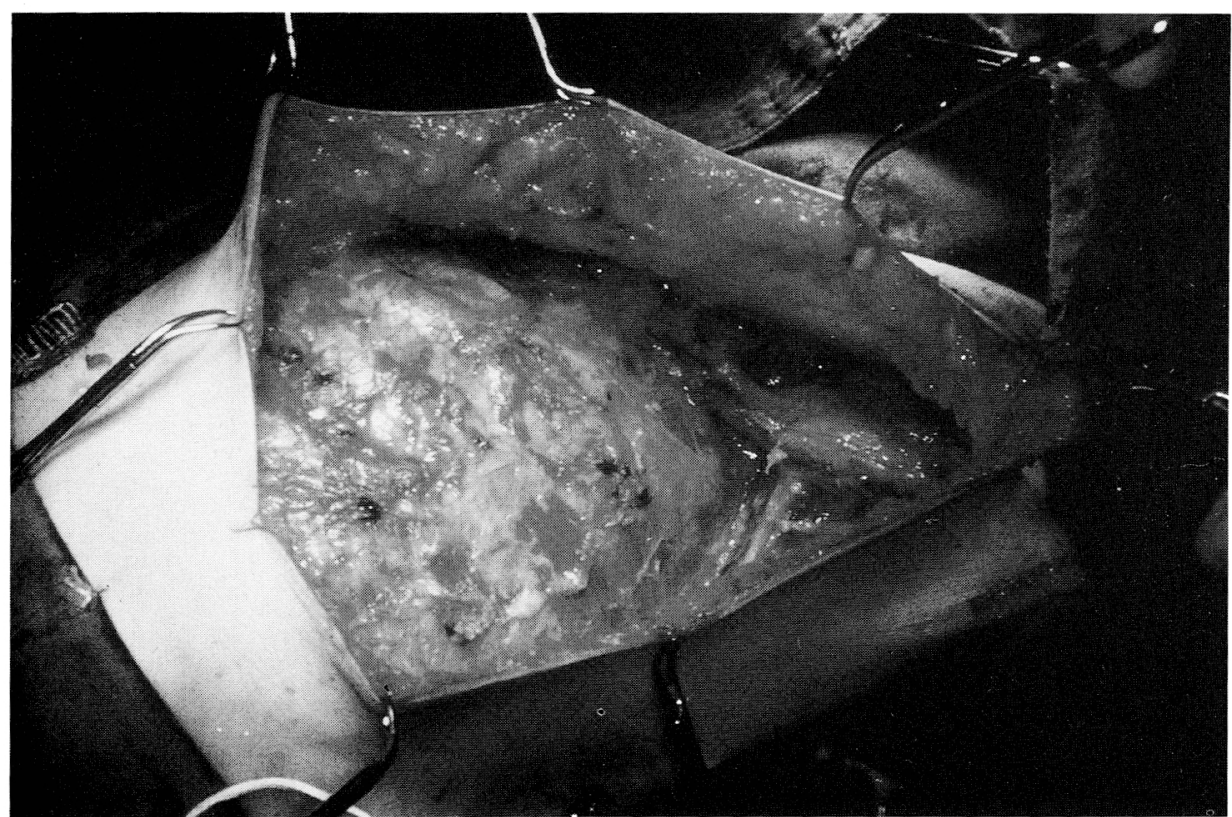

図11

結＼cjkstart果

上述の方法を用いて施行した乳癌根治術症例 と、マイクロ波メスを使用せず手術を施行した 症例とを比較した。定型的乳房切断術では手術 時間, 出血量とも大きな差は認められなかっ た。しかしマイクロターゼ使用群において,ド レーン留置期間がやや短い傾向が認められ, 非 使用群で 9 例中 5 例にリンパ液貯留が認められ たのに対し，使用群では 4 例中 1 例に認められ たのみであった。非定型的乳房切断術では使用 群において出血量の減少が認められた(表 1 , 2 )。しかし, 非使用群では合併症が認められ なかったのに対し，使用群では11例中 3 例にリ ンパ液貯留，1例に創哆開が認められた（表 3)。
考察

現在までマイクロターゼは, 肝切除 ${ }^{11}$, 肝癌 自然破裂 ${ }^{12)}$, 膵部分切除 ${ }^{13)}$, 脾部分切除 ${ }^{14)}$, 上

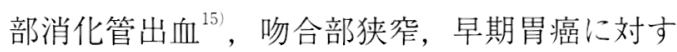
る凝固療法 ${ }^{16}$ 等さまざまな分野に応用され，そ の有用性も実証されている。今回ブレード型マ イクロターゼの開発により，組織を凝固した後 切離するという操作が，凝固しながら切離する という一連の操作で可能となり，これを乳癌根 治術に応用した結果, 術中の結紮操作がほとん ど不要となった。腋窩郭清の際に数回の結紮を 必要とするのみで, 皮下組織の剥離から内胸動 静脈穿通枝の離断まで, 結紮は全く不要であっ た。しかし，充分止血可能な血管を切離してし まい，後で凝固するということも何度かあり， マイクロターゼ使用群と非使用群との間で出血 量の差が大きくなく，使用群で手術時間が長く 
表 1 マイクロ波メス使用群と非使用群との比較 非定型的乳房切断術

\begin{tabular}{l|l|l|l|l|l|l}
\hline & 症例数 & 年 齢 & 手術時間 & 出血量 & $\begin{array}{c}\text { ドレーン } \\
\text { 留置期間 }\end{array}$ & 合併症 \\
\hline 使 用 群 & 11 例 & 50.3 歳 & $2^{\circ} 24^{\prime}$ & $165 \mathrm{ml}$ & 6.0 日 & $4 / 11$ \\
\hline 非使用群 & 5 & 47.0 & $2^{\circ} 01^{\prime}$ & 211 & 6.8 & $0 / 5$ \\
\hline
\end{tabular}

表 2 マイクロ波メス使用群と非使用群との比較 定型的乳房切断術

\begin{tabular}{l|l|l|l|l|l|l}
\hline & 症例数 & 年 路 & 手術時間 & 出血量 & $\begin{array}{c}\text { ドレーン } \\
\text { 留置期間 }\end{array}$ & 合併症 \\
\hline 使 用 群 & 4 例 & 54.0 歳 & $2^{\circ} 15^{\prime}$ & $242 \mathrm{~m} \ell$ & 5.8 日 & $1 / 4$ \\
\hline 非使用群 & 9 & 53.7 & $2^{\circ} 12^{\prime}$ & 267 & 7.1 & $5 / 9$ \\
\hline
\end{tabular}

表 3 合併症

$\begin{array}{cl}\text { マイクロ波メス使用群 } & \text { (15例中5例) } \\ \text { リンパ液貯留 } & 4 \text { 例 } \\ \text { 創哆開 } & 1 \text { 例 } \\ & \\ \text { マイクロ波メス非使用群 } & (14 \text { 例中 5 例 }) \\ \text { リンパ液貯留 } & 5 \text { 例 }\end{array}$

なっているのは, メスの移動速度が速すぎたた めに出血し, その止血操作に時間がかかったた めと考えられる。症例を重ねるうちに組織を切 離する際, メスの先端を $1 \mathrm{~cm} / \mathrm{sec} て ゙$ 移動させる と, 切離面からの出血は認められず, 無血的な 術野が得られることがわかった。この速度で組 織を切離すれば, より少ない出血量, 短い手術 時間で手術が可能と考えられる。

合併症は両者にほぼ同等に認められたが，マ イクロターゼによると考えられる特殊な合併症
は認められなかった。非定型的乳房切断術で 1 例認められた創哆開は皮膚の緊張のために生じ たものであり, マイクロターゼが直接関与した ものではなかった。

ブレード型マイクロターゼは乳癌根治術だけ でなく, 他の手術にも応用可能であり, 今後種 々の手術に利用できると考えられる。

$$
\text { まとめ }
$$

1. 乳癌根治術におけるブレード型マイクロ波 メスの使用経験を報告した。

2.ブレード型マイクロ波メスの止血力によ り，電気メスを一切使用せず数回の結紮にて 乳癌根治術が可能となった。

3.ブレード型マイクロ波メスは乳癌根治術だ けでなく, 種々の手術に応用可能と考えられ た。 


\section{文 献}

1）金田道弘：悪性腫瘍に及ぼす輸血の影響とその機 序に関する研究. 岡山医学会雑誌，99(11，12）： 1391-1401，1987。

2) Alex G. Little, Huai-Shen Wu, Mark K. Ferguson et al. : Perioperative Blood Transfusion Adversely Affects. Prognosis of Patients with Stage I NonSmall-Cell Lung Cancer. Am J Surg, 160 (12) : 630-633, 1990.

3 ）今泉宗久, 内田達男, 新美隆男他: 肺癌手術にお ける輸血の影響に関する研究. 日臨外会誌，50 (4) :658-663，1989。

4) Sunao Moriguchi, Yoshihiko Maehara, Kouhei Akazawa et al. : Lack of Relationship Between Perioperative Blood Transfusion and Survival Time After Curative Resection for Gastric Cancer. Cancer, 66:2331-2335, 1990.

$5 ）$ 金光敬祐，沢井清司，岡野晋治他：周手術期の輸 血が胃癌の生存率に及ぼす影響に関する検討。日 消外会誌，24(8)：2119-2125，1991。

6 ) Riad N. Younes, Andre Rogatko and Murray F. Brennan. : The Influence of Intraoperative Hypotension and Perioperative Blood Transfusion on Disease-free Survival in Patients with Complete Resection of Colorectal Liver Metastasis. Ann Surg, 214 (2) : 107-113, 1991.

7) Tartter PI, Burrows L, Papatestas AE et al. : Perioperative blood transfusion has prognostic significance for breast cancer. Surgery, $97: 225-$ 229, 1985.

8）八木田旭那, 竹内教能, 伊藤久他: 結腸癌と乳癌 の予後に与える輸血の影響. 医学のあゆみ，139： 119-120，1986。

9）鈴木真一, 土屋敦雄, 野水整他：乳癌の予後に及 ぼす輸血の影響．外科診療，29 (12)：1737-1741, 1987 。

10）田伏克惊, 山本誠己, 坂口雅宏他：Microwave 新 型メス (blade 型電極) を用いた外科手術. 日本医 事新報，3557：37-40，1992。

11）田伏克惊，勝見正治，小林康人他：手術の要点と 新工夫一肝癌 -6 . Microwave Surgery. 一肝切除 術一。臨外会誌，44：475-479，1983。

12）田伏克惊, 勝見正治, 小林康人他: 原発性肝癌自 然破裂症に対する Microwave Coagulation Therapy
の適応とその意義. 日消外会誌，15（7）：11961202，1982。

13）小林康人, 田伏克惊, 青山修他：膵に扔けるマイ クロ波凝固の影響について一肝実質, 胃粘膜との 比較検討 -. 最新医学, 38 (10)：2108-2110, 1983。

14) Tabuse, K. and Katsumi, M. : Microwave tissue coagulator in partial splenectomy for nonparasitic splenic cyst. Arch. Jpn. Chir., 50 : 711-717, 1981.

15）永井祐吾, 谷村弘, 上畑清文他: 上部消化管出血 に対する内視鏡的マイク口波凝固法. 消化器科, 14(1) : 39-48，1991。

16) 永井祐吾, 勝見正治, 田伏克惊他: 早期胃癌に対 する内視鏡的マイクロ波凝固療法の検討. Gastroenterol. Endosc., 28(7) : 1511-1518，1986。 